\title{
EFFECT OF IRRIGATION WATER QUANTITY, SOURCES AND RATES OF NITROGEN ON GROWTH AND QUALITY Of SUGAR BEET \\ Soliman, E. M. ${ }^{1}$; M. A. El - Hawary ${ }^{2}$; I. M. Abdel-Aziz ${ }^{3}$; O. A. O. Mazen and Shadia A. Mohamed ${ }^{3}$ \\ 1 Inst. of Environ. Studies and Res., Ain Shams Univ. \\ ${ }^{2}$ Agronomy Dept. Fac. Agric., Al-Azhar Univ., Cairo. \\ ${ }^{3}$ Soils, Water and Environ. Res. Inst., Agric. Res. Center, Giza, Egypt.
}

\begin{abstract}
Two field experiments were carried out at Sakha Agric. Res. Station, Kafr ElSheikh Governorate, Egypt during 2010/2011 and 2011/2012 seasons, to study the effect of three irrigation water quantity $\left(3000,2500\right.$ and $\left.2000 \mathrm{~m}^{3}\right)$, four nitrogen sources (Urea 46.5\% N, Ammonium sulfate $20.6 \% \mathrm{~N}$, Ammonium nitrate $33.5 \% \mathrm{~N}$ and Anhydrous ammonia $82 \% \mathrm{~N}$ ) and three nitrogen rates $(70,80$ and $90 \mathrm{~kg} \mathrm{~N} / \mathrm{fed}$.) on growth yield and quality of sugar beet c.v. Gloriuf . The experiments were laid out in split plot design with four replications.

The obtained results indicated that decreasing amount of irrigation water from $3000 \mathrm{~m}^{3}$ to 2500 and $2000 \mathrm{~m}^{3}$ caused reduction in root fresh weight, a amino nitrogen and potassium\%. On the other hand, reducing irrigation level from $3000 \mathrm{~m}^{3}$ to 2500 and $2000 \mathrm{~m}^{3}$ increased root length, sodium percentage as well as purity percentage.

Sugar beet plants received anhydrous ammonia gave the highest values of root length, root fresh weight, potassium and purity percentage, on the other hand, it gave the lowest values of $\alpha$ amino nitrogen and Sodium percentage.

Sugar beet plants fertilized with nitrogen fertilizer at the rate of $90 \mathrm{~kg} \mathrm{~N} / \mathrm{fed}$. gave the highest values of root length, root fresh weight, potassium percentage and a amino nitrogen percentage, while the highest values of sodium percentage and purity percentage were recorded with plants received nitrogen fertilizer at the rate of $70 \mathrm{~kg}$ $\mathrm{N} /$ fed. as compared with other nitrogen fertilizer rates .

At all irrigation levels nitrogen fertilizer application in the form of anhydrous ammonia gave the highest values of root length, root fresh weight, potassium\% and purity $\%$, but it gave the lowest values of $\alpha$ amino nitrogen $\%$ and sodium percentage .At the highest water regime $\left(2000 \mathrm{~m}^{3} / \mathrm{fed}\right.$.) raising nitrogen fertilizer from 70 to $90 \mathrm{~kg}$ $\mathrm{N} / \mathrm{fed}$. increased root length , root fresh weight , $\alpha$ amino nitrogen $\%$ and potassium $\%$ , on the contrary the highest $\mathrm{Na}$ and purity\% were found with $70 \mathrm{~kg} \mathrm{~N} / \mathrm{fed}$. At all nitrogen fertilizer rates plants received nitrogen in the form of anhydrous ammonia gave the highest values of root length, root fresh weight and purity\%, on the other hand, this treatment gave the lowest values of $\alpha$ amino nitrogen $\%$ percentage and sodium percentage.

At the highest water regime $\left(2000 \mathrm{~m}^{3} / \mathrm{fed}\right.$.) plants fertilized by nitrogen fertilizer at the rate of $90 \mathrm{~kg} \mathrm{~N} / \mathrm{fed}$. in the form of anhydrous ammonia gave the longest root, heaviest roots, potassium percentage and purity percentage, on the contrary it gave the lowest $\alpha$ amino nitrogen percentage ,sodium percentage.

Generally, it could be concluded that when the shortage of irrigation water was presented, fertilizing sugar beet plants with nitrogen fertilizer in the form of anhydrous ammonia at the rate of $90 \mathrm{~kg} \mathrm{~N} / \mathrm{fed}$. improved growth and root juice quality of sugar beet plants at Sakha Kafr El-Sheikh Governorate conditions.
\end{abstract}




\section{INTRODUCTION}

Sugar beet (Beta vulgaris, L.) ranks the second important sugar crop after sugar cane, producing annually $45 \%$ of sugar production all over the world. The Egyptian Government encourages sugar beet growers to increase the cultivated area for decreasing the gap between sugar production and consumption. This increase is likely to be obtained by increasing root and sugar production as well as decreasing sugar losses into molasses. The aim of sugar beet processors worldwide is to produce pure sugar at least expense from the roots which they have purchased and which represent their major manufacturing cost. The efficiency of processing depends on the root quality which is by far the most important parameter affecting processing. In order to understand the relationship between root quality and processing efficiency it is necessary to know the chemical constituents of beet root and raw juice. The significant of the amino acids as well as potassium and sodium has necessarily had to be taken into account in almost all calculation aimed at assessing the contribution of the non sugar to potential loss of sugar into molasses.

The quantity of water required to produce maximum root and sugar yields as well as juice quality are important as water stress limits plant growth and consequently reduce root yield and quality (Parashar et al., 1976). Ramazan et al. (2011) found that increasing water deficits resulted in a relatively lower white sugar yields.

Source of nitrogen application is important management tools in this respect because maximum nitrogen efficiency is obtained when nitrogen is applied in the form which is available for uptake by plant needed. Leilah et al. (2005), revealed that nitrogen fertilizer source as ammonium sulphate had significant effect on all growth parameters of sugar beet plants i.e. root length and fresh weight of roots compared to control. Nemeat-Alla (2009) and ElSonbaty et al. (2012), declared that fertilizing sugar beet plants with urea $(46 \% \mathrm{~N})$ improved plant growth(length and fresh weight of root) compared to untreated plants.

Nitrogen is a major nutrient element and its needed in large amount for high yield of sugar beet and it considered the most factor affecting the growth and productivity of sugar beet. Tsialtas and Masalris (2005) showed that non sugar impurities ( $\mathrm{K}, \mathrm{Na}$ and alpha amino nitrogen ) were positively related to the increasing nitrogen rate. El-Sarag (2009) and Nemeat, Alla (2009) found that increasing nitrogen up to $120 \mathrm{~kg} \mathrm{~N} / \mathrm{fed}$ increased root length and root fresh weight of sugar beet. Fathy and Attia (2009) reported that increasing nitrogen level up to $285 \mathrm{~kg} \mathrm{~N} / \mathrm{ha}$ increased impurities ( $\mathrm{Na}, \mathrm{K}$ and alpha amino nitrogen) in juice of sugar beet. Abd- El-kader (2011) found that average potassium and sodium \% were significantly affected by nitrogen fertilizer rates .Increasing nitrogen fertilizer rate from 0 to $110 \mathrm{kgN} / \mathrm{fed}$. increased potassium \%, on the other hand decreased sodium $\%$.

The aim of the present investigation is to study the effect of irrigation water quantity, nitrogen sources and nitrogen rates on sugar beet growth and juice quality at Sakha, Kafr El-Sheikh Governorate conditions, Egypt. 


\section{MATERIALS AND METHODS}

Two field experiments were carried out at Sakha Agricultural Research station, Kafr El-Sheikh Governorate, Egypt during 2010/2011 and $2011 / 2012$ seasons, to study the effect of irrigation water quantity, nitrogen sources and rates on growth and juice quality of sugar beet, cv. Gloriuf.

Soil samples were randomly taken from the experimental sites at depth of 0 to $30 \mathrm{~cm}$ from soil surface and were prepared for physical and chemical properties in 2010/2011 and 2011/2012 seasons according to Chapman and Pratt (1961). Physical and chemical properties of soil at the experimental sites in both seasons are shown in Table (1). The preceding summer crop was rice in both seasons.

The experiments treatments were as follows:

I-Irrigation water quantity

Three irrigation water quantity were applied as follows:

1. Applied $2000 \mathrm{~m}^{3}$ water/fed.

2. Applied $2500 \mathrm{~m}^{3}$ water/fed.

3. Applied $3000 \mathrm{~m}^{3}$ water/fed.

All irrigation treatments were received the same sowing irrigation in both seasons. The irrigation water quantity were contained water amount of rainfall in both seasons as shown in Table (2). The irrigation treatments were started at 30 days from sowing.

Table 1: Physical and Chemical Properties of the experimental Soil:

\begin{tabular}{|c|c|c|}
\hline Coil Dranartiso & & \\
\hline Soil Properties & $2010 / 2011$ & 2011/2012 \\
\hline A. Physical analysis (soil fraction) & & \\
\hline Sand \% & 19.5 & 17.9 \\
\hline Silt \% & 24.5 & 23.6 \\
\hline Clay \% & 56 & 58.5 \\
\hline Texture Class & Clay & Clay \\
\hline Sp \% & 64 & 65 \\
\hline B. Chemical analysis & & \\
\hline $\mathrm{PH}(1: 2.5)$ & 7.9 & 8 \\
\hline $\mathrm{EC}(\mathrm{dS} / \mathrm{m})$ & 0.99 & 0.98 \\
\hline $\mathrm{Ca} \mathrm{CO} 3 \%$ & 4 & 3.89 \\
\hline Soluble anions in extract & & \\
\hline $\begin{array}{ll}\mathrm{HCO}_{3}^{-} & (\mathrm{meq} / \mathrm{L}) \\
\end{array}$ & 4 & 3.7 \\
\hline $\mathrm{Cl} \quad(\mathrm{meg} / \mathrm{L})$ & 2.54 & 3.38 \\
\hline $\mathrm{SO}{ }_{4} \quad(\mathrm{meq} / \mathrm{L})$ & 3.42 & 2.79 \\
\hline Soluble cations in extract & & \\
\hline (meg/L) & 5 & 4.58 \\
\hline$(\mathrm{meg} / \mathrm{L})$ & 0.4 & 0.57 \\
\hline $\mathrm{Ca}^{++} \quad(\mathrm{meg} / \mathrm{L})$ & 3.1 & 2.85 \\
\hline $\mathrm{Mq}^{++} \quad(\mathrm{meg} / \mathrm{L})$ & 1.46 & 1.7 \\
\hline Total N \% & 0.17 & 0.16 \\
\hline Available & 14 & 13 \\
\hline $\mathrm{P}(\mathrm{ppm})$ & 8.2 & 7.9 \\
\hline $\mathrm{K}$ (ppm) & 420 & 413 \\
\hline
\end{tabular}


Soliman, E. M. et al.

Table 2 : Quantity of seasonal irrigation water (IW) and rainfall water (R) applied to sugar beet in both seasons .

\begin{tabular}{|l|c|c|c|c|}
\hline \multirow{2}{*}{$\begin{array}{c}\text { Irrigation regime } \mathbf{( m}^{\mathbf{3}} \\
\text { /fed.) }\end{array}$} & \multicolumn{2}{|c|}{$\mathbf{2 0 1 0 / 2 0 1 1}$ season } & \multicolumn{2}{|c|}{$\mathbf{2 0 1 1 / 2 0 1 2}$ season } \\
\cline { 2 - 5 } & $\mathbf{I W}$ & $\mathbf{R}$ & $\mathbf{I W}$ & $\mathbf{R}$ \\
\hline 2000 & 1844.6 & 155.4 & 1470.5 & 529.5 \\
\hline 2500 & 2344.6 & 155.4 & 1970.5 & 529.5 \\
\hline 3000 & 2844.6 & 155.4 & 2470.5 & 529.5 \\
\hline
\end{tabular}

\section{II-Nitrogen sources}

Four nitrogen sources studied were as follows:

1 -Urea $(46.5 \% \mathrm{~N})$.

2-Ammonium sulphate $(20.6 \% \mathrm{~N})$.

3-Ammonium nitrate $(33.5 \% \mathrm{~N})$.

4-Anhydrous ammonia ( $82 \% \mathrm{~N})$.

Anhydrous ammonia fertilizer $(82 \% \mathrm{~N})$ was injected into the soil at four days sowing using ammonia applicator device, while depth of injection was $20 \mathrm{~cm}$ in soil containing $15 \%$ moisture content.

\section{III- Nitrogen fertilizer rates}

Three nitrogen rates were applied as follows:

1-Applied 70kg N/fed.

2-Applied $80 \mathrm{~kg} \mathrm{~N} / \mathrm{fed}$.

3-Applied $90 \mathrm{~kg} \mathrm{~N} / \mathrm{fed}$.

The three nitrogen rates from urea, ammonium sulfate and ammonium nitrate were added in two equal split doses, one at 45 days from sowing and the second at 75 days from sowing.

The experiments were carried out in split plot design with four replications. The irrigation treatments were randomly distributed in main plots, while nitrogen sources and rates were allocated at random in sub plots. The area of sub plot was $21 \mathrm{~m}^{2}$ (7rows $\times 0.6 \mathrm{~m}$ width $\times 5 \mathrm{~m}$ length). Main plots (irrigation treatments) were isolated by ditches $1.5 \mathrm{~m}$ in width to avoid lateral movement of water.

The experiment soil was prepared as usually and potassium as potassium sulphate $48 \% \mathrm{~K}_{2} \mathrm{O}$ as well as phosphorus as superphosphate $15.5 \% \mathrm{P}_{2} \mathrm{O}_{5}$ were added at the rate of $100 \mathrm{~kg} \mathrm{fed}^{-1}$ from both the two fertilizers before planting for all plots. Seeds were hand sown on 16 and 25 August in 2010/2011 and 2011/2012 seasons, respectively. Plants were thinned to one plants/hill after 35 days from sowing. Other cultural practices were done as recommended for sugar beet crop usually followed in the region.

The collected data in the experiment involved the following traits:

\section{Data recorded}

At harvest time five plants were chosen randomly from each sub -sub plot and the following traits were measured .

1-Root length $(\mathrm{cm})$.

2-Root fresh weight $(\mathrm{g})$.

3-Potassium percentage in juice .

4-Sodium percentage in juice.

5-Alpha amino nitrogen in juice. 
6-Purity percentage .

Statistical Analysis

The analysis of variance was carried out according to Gomez and Gomez (1984).

\section{RESULTS AND DISCUSSION}

Average root length $(\mathrm{cm})$, root fresh weight $(\mathrm{g}), \alpha$ amino nitrogen percentage, potassium percentage, sodium percentage and purity percentage in root juice of sugar beet as affected by irrigation water quantity, sources and rates of nitrogen fertilizer as well as their interactions in 2010/2011 and 2011/2012 seasons are shown in Tables 3-8.

Results recorded in Tables 3-8 indicate that the effect of irrigation water quantity was significant on all studied traits in both seasons. Decreasing amount of irrigation water from $3000 \mathrm{~m}^{3}$ to 2500 and $2000 \mathrm{~m}^{3}$ caused reduction in root fresh weight by 8.05 and $16.40 \%$, a amino nitrogen by 0.37 and $0.67 \%$ as well as potassium percentage by 0.13 and $0.44 \%$ in $2010 / 2011$ season, respectively, while in 2011/2012 season the corresponding values were 7.63 and $11.22 \%, 0.27$ and $0.48 \%$ as well as 0.12 and $0.30 \%$ in the same respect. On the other hand, reducing irrigation level from $3000 \mathrm{~m}^{3}$ to 2500 and $2000 \mathrm{~m}^{3}$ increased root length by 6.79 and $15.13 \%$ as well as 8.50 and $16.58 \%$, sodium percentage by 0.13 and $0.19 \%$ as well as 0.12 and $0.20 \%$ and purity percentage by 1.05 and $2.70 \%$ as well as 1.63 and $2.95 \%$ in 2010/2011 and 2011/2012 seasons, respectively. The reduction in root fresh weight caused by decreasing irrigation water level may be attributed to the deleterious effect of water deficit on cell elongation and division as well as cell number which led to produce the smaller root having the slight weight. On the contrary, the increase in purity\% due to the lowest level of irrigation was might be attributed to the increase in sucrose $\%$ and $\mathrm{k} \%$ as well as the reduction in a amino nitrogen percentage, thus impurities decreased and increasing purity\% in root juice of sugar beet. These results are in harmony with those of Parashar et al. (1976) and Ramazan et al. (2011)

Results recorded in Tables 3 to 8 show clearly that all measured characters were significantly affected by nitrogen sources in both seasons.

Sugar beet plants received anhydrous ammonia gave the highest values of root length 35.3 and $32.62 \mathrm{~cm}$, root fresh weight 828.89 and $843.00 \mathrm{~g}$, potassium percentage 6.01 and $6.22 \%$ and purity percentage 83.53 and $84.81 \%$. on the other hand, it gave the lowest values of $\alpha$ amino nitrogen percentage 1.55 and $1.50 \%$ and Sodium percentage 1.67 and $1.77 \%$ compared to all other nitrogen sources in 2010/2011 and 2011/2012 seasons, respectively. The superiority of anhydrous ammonia of growth and quality than other nitrogen sources may be due to it had maximum nitrogen efficiency and available for uptake by plants as well as it gave the highest values of growth traits and the lowest values of $\alpha$ amino $\mathrm{N}$ therefore, it gave the higher values of growth and juice purity\% of sugar beet. These results are in harmony with those of Nemeat-Alla (2009) and El-Sonbaty et al. (2012). 
Results presented in Tables 3 to 8 show clearly that the effect of nitrogen rates was significant on all studied characters in both seasons.

Sugar beet plants fertilized with nitrogen fertilizer at the rate of $90 \mathrm{~kg}$ $\mathrm{N} / \mathrm{fed}$. gave the highest values of root length 32.46 and $30.48 \mathrm{~cm}$, root fresh weight 810.25 and $833.83 \mathrm{~g}$, a amino nitrogen percentage 1.99 and $1.85 \%$ and potassium percentage 6.23 and $6.33 \%$, while the highest values of sodium percentage 1.88 and $2.01 \%$ and purity percentage 82.60 and $84.00 \%$ were recorded with plants received nitrogen fertilizer at the rate of $70 \mathrm{~kg}$ $\mathrm{N} / \mathrm{fed}$. as compared with other nitrogen fertilizer rates in 2010/2011 and 2011/2012 seasons, respectively.

The increment of root fresh weight owing to raising nitrogen rate might be attributed to the active effect of nitrogen in increasing photosynthesis and net assimilation rate trans located and stored in roots which led to increasing root length resulted in increasing root fresh weight. On the other hand, the increase in purity\% caused by the lowest nitrogen rate may be due to the reduction in root length and root fresh weight resulted from smaller roots which have the lowest wetted, therefore increased sucrose concentration, thus increased purity\%. These results are in agreement with those of Fathy and Attia (2009) and Abd-El-kader (2011).

The obtained resulted show that the interaction effect between irrigation water amounts and nitrogen sources was significant on all studied characters in both seasons. At all irrigation levels nitrogen fertilizer application in the form of anhydrous ammonia gave the highest values of root length, root fresh weight and potassium\%, but it gave the lowest values of $a$ amino nitrogen\% and sodium percentage as compared with all other interaction treatments in both seasons. However, at the lowest irrigation level $\left(2000 \mathrm{~m}^{3} / \mathrm{fed}\right.$.) plants received anhydrous ammonia gave 7.56 and $5.17 \%$ increase in root fresh weight compared to Urea ,also it gave the highest purity $\% 85.60$ and $87.10 \%$ in $2010 / 2011$ and $2011 / 2012$ seasons, respectively.

Results tabulated in Tables 3 to 8 exhibited that the interaction effect among irrigation water quantity and nitrogen fertilizer rates significantly affected all measured studied in both seasons. At all irrigation levels, increasing nitrogen fertilizer rate significantly increased values of all studied traits in both seasons. At the highest water regime $\left(2000 \mathrm{~m}^{3} / \mathrm{fed}\right.$.) raising nitrogen fertilizer from 70 to $90 \mathrm{~kg} \mathrm{~N} / \mathrm{fed}$. increased root length by 10.61 and $12.91 \%$, root fresh weight by 11.81 and $10.24 \%$, $\alpha$ amino nitrogen $\%$ by 0.35 and $0.35 \%$ and potassium $\%$ by 0.67 and $0.53 \%$ as compared with other treatments in 2010/2011 and 2011/2012 seasons, respectively. The highest $\mathrm{Na} \% 1.96$ and $2.08 \%$ and purity\% 83.95 and $85.20 \%$ were found with plants grown on the lowest irrigation level $\left(2000 \mathrm{~m}^{3} / \mathrm{fed}\right.$.) and $70 \mathrm{~kg} \mathrm{~N} / \mathrm{fed}$. fertilizer compared to all other interaction treatments in 2010/2011 and 2011/2012 seasons, respectively.

Results recorded in Tables 3-8 show that all studied traits significantly affected by the interaction between nitrogen sources and nitrogen rates in both seasons. At all nitrogen fertilizer rates plants received nitrogen in the form of anhydrous ammonia gave the highest values of root length, root fresh weight and purity\%, on the other hand, this treatment gave 
the lowest values of $\alpha$ amino nitrogen acids percentage and sodium percentage compared to all other this interaction treatments in both seasons. The obtained results indicated that the interaction effect between irrigation levels, nitrogen sources and nitrogen rates was significant on all studied characters in both seasons. At the highest water regime $\left(2000 \mathrm{~m}^{3} / \mathrm{fed}\right.$.) plants fertilizer by nitrogen fertilizer at the rate of $90 \mathrm{~kg} \mathrm{~N} / \mathrm{fed}$. in the form of anhydrous ammonia gave the longest root 39.7 and $37.0 \mathrm{~cm}$, heaviest roots 820.00 and $860.09 \mathrm{~g}$ and potassium percentage 6.11 and $6.35 \%$, on the contrary it gave the lowest $\alpha$ amino nitrogen percentage 1.10 and $1.04 \%$ and sodium percentage 1.63 and $1.74 \%$, while this treatment gave the highest purity $\% 86.20$ and $88.10 \%$ as compared with all other this interaction treatments in 2010/2011 and 2011/2012 seasons, respectively.

Generally, it could be concluded that when the shortage of irrigation water was presented, fertilizing sugar beet plants with nitrogen fertilizer in the form of anhydrous ammonia at the rate of $90 \mathrm{~kg} \mathrm{~N} / \mathrm{fed}$. improved growth and root juice quality of sugar beet plants c.v.Gloriuf at Sakha Kafr El-Sheikh Governorate conditions.

Table 3 : Average root length $(\mathrm{cm})$ of sugar beet as affected by irrigation regime, nitrogen sources, nitrogen rates and their interactions in 2010/2011 and 2011/2012 seasons.

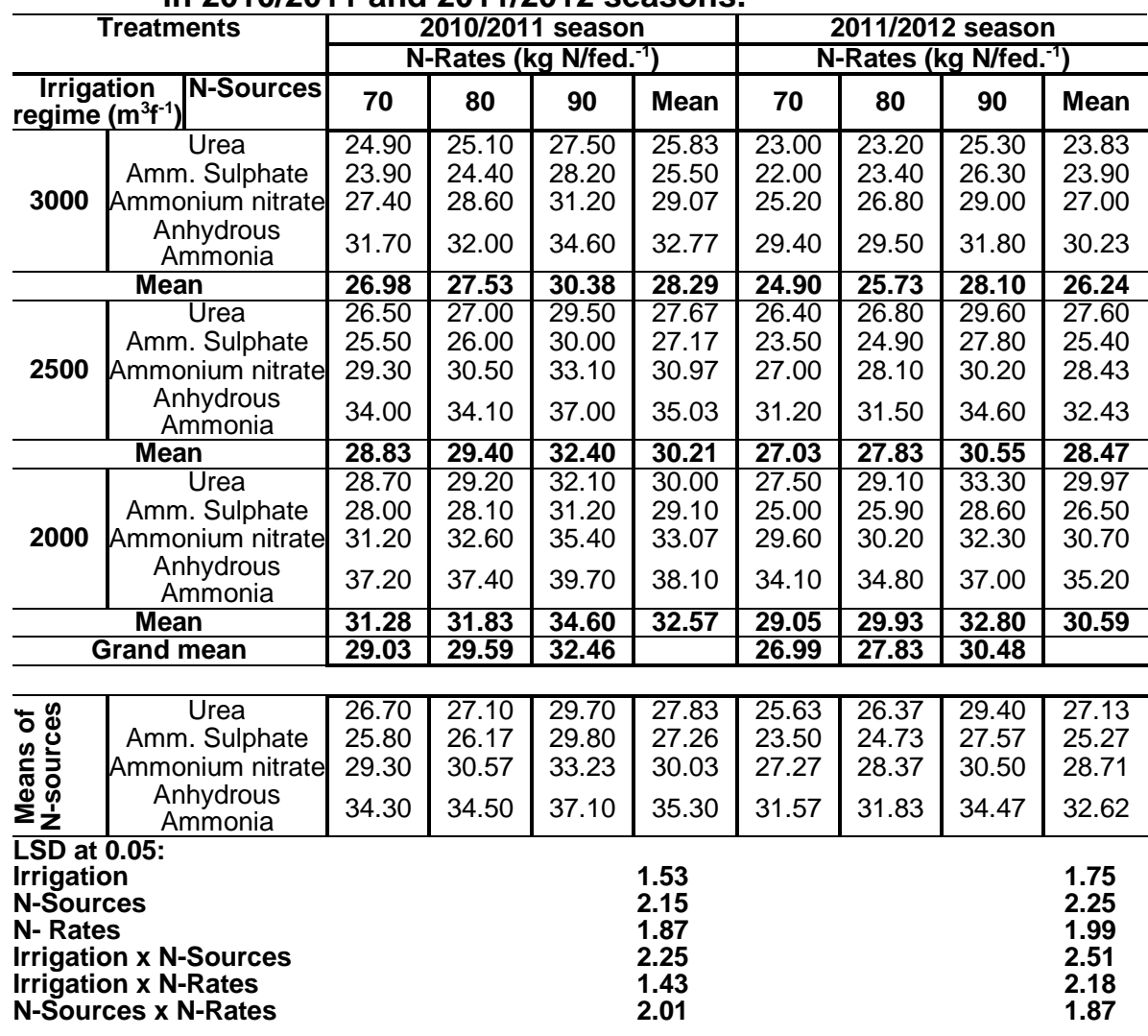


Soliman, E. M. et al.

Table 4: Average root fresh weight $(\mathrm{g})$ at harvest of sugar beet as affected by irrigation regime, nitrogen sources, nitrogen rates and their interactions in 2010/2011 and 2011/2012 seasons.

\begin{tabular}{|c|c|c|c|c|c|c|c|c|c|c|}
\hline \multirow{2}{*}{\multicolumn{3}{|c|}{ Treatments }} & \multirow{2}{*}{\multicolumn{4}{|c|}{$\begin{array}{c}\text { 2010/2011 season } \\
\text { N-Rates }\left({\left.\mathrm{kg} \mathrm{N} / \text { fed }^{-1}\right)}\right.\end{array}$}} & \multirow{2}{*}{\multicolumn{4}{|c|}{$\begin{array}{c}\text { 2011/2012 season } \\
\text { N-Rates }\left(\mathrm{kg} \mathrm{N} / \mathrm{fed}^{-1}\right)\end{array}$}} \\
\hline & & & & & & & & & & \\
\hline \multicolumn{2}{|c|}{$\begin{array}{c}\text { Irrigation } \\
\text { regime } \\
\left(\mathrm{m}^{3} \mathrm{f}^{-1}\right)\end{array}$} & $\begin{array}{c}\mathrm{N}- \\
\text { Sources }\end{array}$ & 70 & 80 & 90 & Mean & 70 & 80 & 90 & Mean \\
\hline \multirow{4}{*}{3000} & & Urea & 770 & 847 & 880 & 832.33 & 810 & 833 & 893 & 845.33 \\
\hline & & $\begin{array}{l}\text { Amm. } \\
\text { ulphate }\end{array}$ & 743 & 780 & 857 & 793.33 & 777 & 817 & 843 & 812.33 \\
\hline & $\mathrm{Am}_{\mathrm{r}}$ & $\begin{array}{l}\text { nmonium } \\
\text { nitrate }\end{array}$ & 753 & 880 & 863 & 832.00 & 787 & 827 & 870 & 828.00 \\
\hline & & $\begin{array}{l}\text { hydrous } \\
\text { mmonia }\end{array}$ & 830 & 880 & 937 & 882.33 & 840 & 877 & 963 & 893.33 \\
\hline \multicolumn{3}{|c|}{ Mean } & 774 & 846.75 & 884.25 & 835.00 & 803.50 & 838.50 & 892.25 & 844.75 \\
\hline \multirow{4}{*}{2500} & & Urea & 737 & 763 & 807 & 769.00 & 767 & 787 & 817 & 790.33 \\
\hline & & $\begin{array}{l}\text { Amm. } \\
\text { ulphate }\end{array}$ & 607 & 760 & 783 & 716.67 & 660 & 750 & 773 & 727.67 \\
\hline & $\mathrm{Am}_{\mathrm{r}}$ & $\begin{array}{l}\text { nmonium } \\
\text { nitrate }\end{array}$ & 736 & 750 & 790 & 758.67 & 753 & 773 & 817 & 781.00 \\
\hline & & $\begin{array}{l}\text { hydrous } \\
\text { mmonia }\end{array}$ & 780 & 830 & 870 & 826.67 & 773 & 817 & 877 & 822.33 \\
\hline \multicolumn{3}{|c|}{ Mean } & 715 & 775.75 & 812.50 & 767.75 & 738.25 & 781.75 & 821 & 780.33 \\
\hline \multirow{4}{*}{2000} & & Urea & 683 & 723 & 763 & 723 & 770 & 787 & 763 & 773.33 \\
\hline & & $\begin{array}{l}\text { Amm. } \\
\text { ulphate }\end{array}$ & 583 & 653 & 670 & 635.33 & 630 & 670 & 750 & 683.33 \\
\hline & $\mathrm{Am}_{\mathrm{r}}$ & $\begin{array}{l}\text { nmonium } \\
\text { nitrate }\end{array}$ & 630 & 656 & 683 & 656.33 & 683 & 727 & 780 & 730 \\
\hline & & $\begin{array}{l}\text { hydrous } \\
\text { mmonia }\end{array}$ & 730 & 783 & 820 & 777.67 & 777 & 803 & 860 & 813.33 \\
\hline & Mea & an & 656.50 & 703.75 & 734.00 & 698.08 & 715.00 & 746.75 & 788.25 & 750.00 \\
\hline \multicolumn{3}{|c|}{ Grand mean } & 715.17 & 775.42 & 810.25 & & 752.25 & 789.00 & 833.83 & \\
\hline \multirow{4}{*}{ 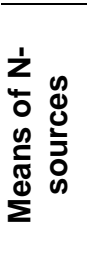 } & & Urea & 730.00 & 777.67 & 816.67 & 774.78 & 782.33 & 802.33 & 824.33 & 803.00 \\
\hline & & $\begin{array}{l}\text { Amm. } \\
\text { ulphate }\end{array}$ & 644.33 & 731.00 & 770.00 & 715.11 & 689.00 & 745.67 & 788.67 & 741.11 \\
\hline & $\begin{array}{r}\mathrm{Am} \\
\mathrm{r}\end{array}$ & $\begin{array}{l}\text { nmonium } \\
\text { nitrate }\end{array}$ & 706.33 & 762.00 & 778.67 & 749.00 & 741.00 & 775.67 & 822.33 & 780.00 \\
\hline & & $\begin{array}{l}\text { ihydrous } \\
\text { mmonia }\end{array}$ & 780.00 & 831.00 & 875.67 & & & & & 843.00 \\
\hline \multicolumn{11}{|c|}{ SD at 0.05: } \\
\hline \multirow{2}{*}{\multicolumn{6}{|c|}{$\begin{array}{l}\text { Irrigation } \\
\mathrm{N} \text {-Sources }\end{array}$}} & 35.50 & & & & 23.10 \\
\hline & & & & & & 27.30 & & & & 29.25 \\
\hline \multirow{2}{*}{\multicolumn{3}{|c|}{$\begin{array}{l}\text { N- Rates } \\
\text { Irrigation } \mathrm{x}\end{array}$}} & & & & 21.10 & & & & 32.16 \\
\hline & & & & & & 28.50 & & & & 33.01 \\
\hline \multicolumn{3}{|c|}{ Irrigation x N-Rates } & & & & 30.20 & & & & 28.12 \\
\hline \multirow{2}{*}{\multicolumn{3}{|c|}{$\begin{array}{l}\text { N-Sources x N-Rates } \\
\text { Irrigation } \times \text { N-Sources }\end{array}$}} & & & & 41.11 & & & & 32.17 \\
\hline & & & & & & 45.15 & & & & 33.09 \\
\hline
\end{tabular}


Table 5: Average a amino nitrogen $\%$ in root juice of sugar beet as affected by irrigation regime, nitrogen sources, nitrogen rates and their interactions in 2010/2011 and 2011/2012 seasons.

\begin{tabular}{|c|c|c|c|c|c|c|c|c|c|c|}
\hline \multirow{2}{*}{\multicolumn{3}{|c|}{ Treatments }} & \multirow{2}{*}{\multicolumn{4}{|c|}{$\begin{array}{l}\text { 2010/2011 season } \\
\text { N-Rates }\left(\mathrm{kg} \mathrm{N} / \mathrm{fed}^{-1}\right)\end{array}$}} & \multirow{2}{*}{\multicolumn{4}{|c|}{$\begin{array}{l}\text { 2011/2012 season } \\
\left.\text { N-Rates (kg N/fed. } .^{-1}\right)\end{array}$}} \\
\hline & & & & & & & & & & \\
\hline \multicolumn{2}{|c|}{$\begin{array}{c}\text { Irrigation } \\
\text { regime }\left(m^{3} f^{-1}\right)\end{array}$} & \begin{tabular}{|c|}
$\mathbf{N}-$ \\
Sources
\end{tabular} & 70 & 80 & 90 & Mean & 70 & 80 & 90 & Mean \\
\hline \multirow{4}{*}{3000} & & Jrea & 1.80 & 2.10 & 2.30 & 2.07 & 1.64 & 1.90 & 2.00 & 1.85 \\
\hline & Amm. & Sulphate & 1.91 & 2.13 & 2.45 & 2.16 & 1.75 & 2.01 & 2.15 & 1.97 \\
\hline & $\begin{array}{r}\mathrm{Amn} \\
\mathrm{ni}\end{array}$ & $\begin{array}{l}\text { nonium } \\
\text { itrate }\end{array}$ & 2.06 & 2.46 & 2.63 & 2.38 & 1.97 & 2.16 & 2.21 & 2.11 \\
\hline & $\begin{array}{l}\text { Anh } \\
\text { Am }\end{array}$ & $\begin{array}{l}\text { ydrous } \\
\text { monia }\end{array}$ & 1.71 & 2.02 & 2.06 & 1.93 & 1.52 & 1.89 & 1.95 & 1.79 \\
\hline \multirow{5}{*}{2500} & Mean & & 1.87 & 2.18 & 2.36 & 2.14 & 1.72 & 1.99 & 2.08 & 1.93 \\
\hline & & Jrea & 1.46 & 1.97 & 2.01 & 1.81 & 1.25 & 1.66 & 1.85 & 1.59 \\
\hline & Amm. & Sulphate & 1.69 & 1.75 & 1.89 & 1.78 & 1.49 & 1.63 & 1.81 & 1.64 \\
\hline & $\begin{array}{r}\text { Amn } \\
n i\end{array}$ & $\begin{array}{l}\text { nonium } \\
\text { itrate }\end{array}$ & 1.60 & 1.90 & 2.15 & 1.88 & 1.52 & 1.91 & 2.04 & 1.82 \\
\hline & $\begin{array}{l}\text { Anh } \\
\text { Am }\end{array}$ & ydrous & 1.35 & 1.60 & 1.83 & 1.59 & 1.46 & 1.50 & 1.76 & 1.57 \\
\hline \multirow{5}{*}{2000} & Mean & & 1.52 & 1.81 & 1.97 & 1.77 & 1.43 & \begin{tabular}{|l|}
1.68 \\
\end{tabular} & 1.87 & 1.66 \\
\hline & & Jrea & 1.11 & 1.19 & 1.38 & 1.23 & 1.19 & 1.56 & 1.60 & 1.45 \\
\hline & Amm. & Sulphate & 1.50 & 1.66 & 1.90 & 1.69 & 1.41 & 1.52 & 1.73 & 1.55 \\
\hline & $\begin{array}{r}\text { Amn } \\
\text { ni }\end{array}$ & $\begin{array}{l}\text { nonium } \\
\text { itrate }\end{array}$ & 1.43 & 1.99 & 2.08 & 1.83 & 1.40 & 1.78 & 1.86 & 1.68 \\
\hline & $\begin{array}{l}\text { Anh } \\
\text { Am }\end{array}$ & $\begin{array}{l}\text { ydrous } \\
\text { imonia }\end{array}$ & 1.10 & 1.15 & 1.18 & 1.14 & 1.04 & 1.12 & 1.24 & 1.13 \\
\hline & Mean & & 1.29 & 1.50 & 1.64 & 1.47 & 1.26 & 1.50 & 1.61 & 1.45 \\
\hline \multicolumn{3}{|c|}{ Grand mean } & 1.56 & 1.83 & 1.99 & & 1.47 & 1.72 & 1.85 & \\
\hline \multirow{5}{*}{ 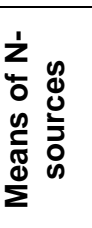 } & & & & & & & & & & \\
\hline & & Jrea & 1.46 & 1.75 & 1.90 & 1.70 & 1.36 & 1.71 & 1.82 & 1.63 \\
\hline & Amm. & Sulphate & 1.70 & 1.85 & 2.08 & 1.88 & 1.55 & 1.72 & 1.90 & 1.72 \\
\hline & $\begin{aligned} \mathrm{Amn} \\
\mathrm{ni}\end{aligned}$ & $\begin{array}{l}\text { nonium } \\
\text { itrate }\end{array}$ & 1.70 & 2.12 & 2.29 & 2.03 & 1.63 & 1.95 & 2.04 & 1.87 \\
\hline & $\begin{array}{l}\text { Anh } \\
\text { Am }\end{array}$ & $\begin{array}{l}\text { iydrous } \\
\text { monia }\end{array}$ & 1.39 & 1.59 & 1.69 & 1.55 & 1.34 & 1.50 & 1.65 & 1.50 \\
\hline \multicolumn{11}{|c|}{ LSD at 0.05: } \\
\hline \multirow{2}{*}{\multicolumn{6}{|c|}{$\begin{array}{l}\text { Irrigation } \\
\text { N-Sources } \\
\text { N-Rates }\end{array}$}} & 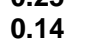 & & & & 0.10 \\
\hline & & & & & & 0.1 & & & & 0.11 \\
\hline \multicolumn{6}{|c|}{ Irrigation $\times$ N-Sources } & 0.1 & & & & 0.07 \\
\hline \multirow{2}{*}{\multicolumn{6}{|c|}{$\begin{array}{l}\text { Irrigation x N-Rates } \\
\text { N-Sources x N-Rates }\end{array}$}} & 0.1 & & & & 0.1 \\
\hline & & & & & & 0.09 & & & & 0.10 \\
\hline \multicolumn{6}{|c|}{$\begin{array}{l}\text { N-Sources } \times \mathrm{N} \text {-Rates } \\
\text { Irrigation x N-Sources x N-Rates }\end{array}$} & 0.13 & & & & 0.11 \\
\hline
\end{tabular}


Soliman, E. M. et al.

Table 6: Average $\mathrm{K} \%$ in roots of sugar beet as affected by irrigation regime, nitrogen sources, nitrogen rates and their interactions in 2010/2011 and 2011/2012 seasons.

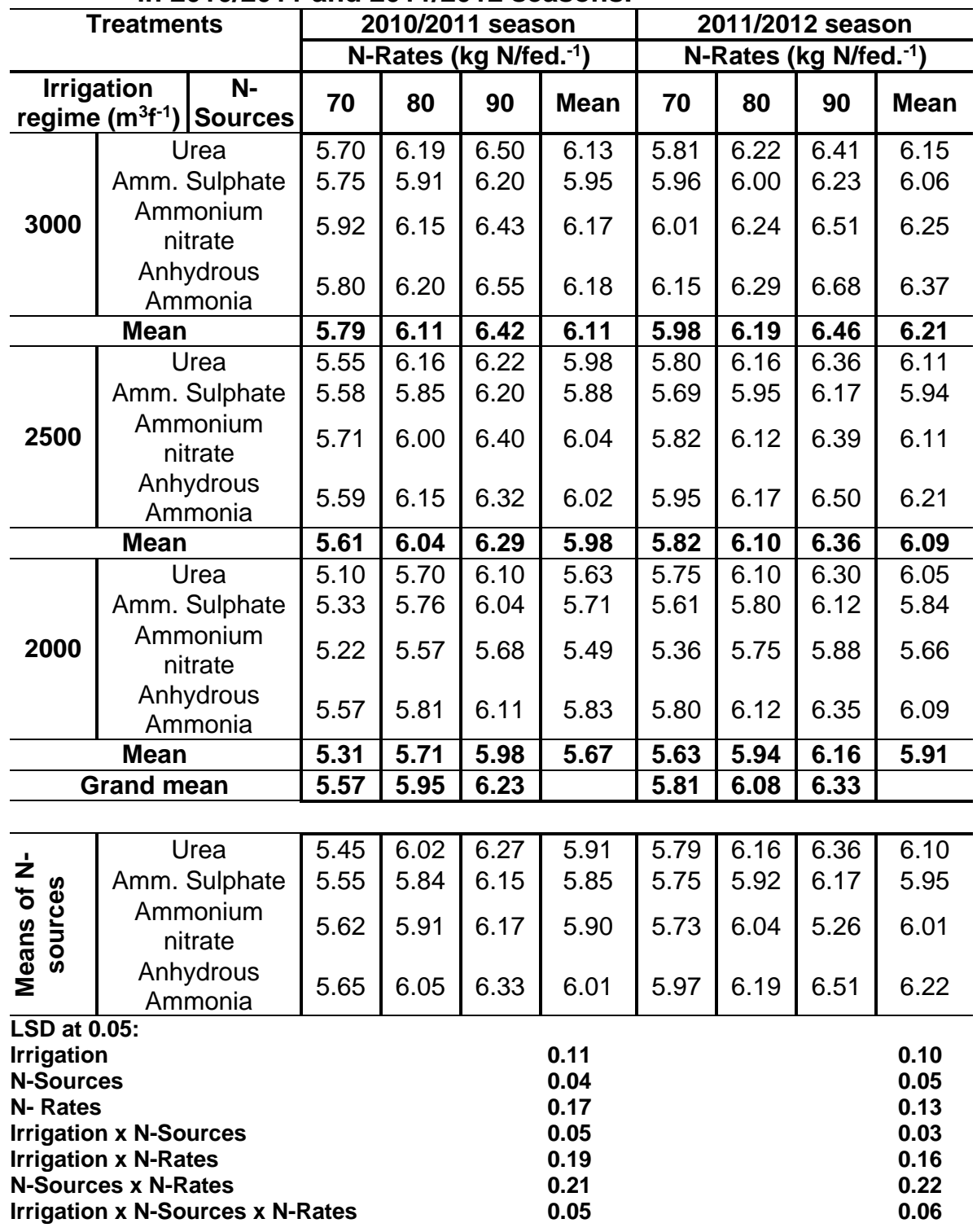


Table 7: Average $\mathrm{Na} \%$ in roots of sugar beet as affected by irrigation regime, nitrogen sources, nitrogen rates and their interactions in 2010/2011 and 2011/2012 seasons.

\begin{tabular}{|c|c|c|c|c|c|c|c|c|c|}
\hline \multicolumn{2}{|r|}{ Treatments } & \multicolumn{4}{|c|}{$\frac{2010 / 2011 \text { season }}{\text { N-Rates }\left(\mathrm{kg} \mathrm{N} / \text { fed. }^{-1}\right)}$} & \multicolumn{4}{|c|}{$\begin{array}{c}\text { 2011/2012 season } \\
\text { N-Rates }\left(\mathrm{kg} \mathrm{N} / \text { fed }^{-1} \text { ) }\right.\end{array}$} \\
\hline $\begin{array}{c}\text { Irrigation } \\
\text { regime }\left(\mathrm{m}^{3} \mathrm{f}^{-1}\right)\end{array}$ & \begin{tabular}{|c|c|} 
ation & $N-$ \\
$\left(m^{3} f^{-1}\right)$ & Sources \\
\end{tabular} & 70 & 80 & 90 & Mean & 70 & 80 & 90 & Mean \\
\hline \multirow{4}{*}{3000} & \multirow{4}{*}{$\begin{array}{c}\text { Urea } \\
\text { Amm. Sulphate } \\
\text { Ammonium } \\
\text { nitrate } \\
\text { Anhydrous } \\
\text { Ammonia }\end{array}$} & 1.80 & 1.72 & 1.53 & 1.68 & 1.84 & 1.75 & 1.61 & 1.73 \\
\hline & & 1.89 & 1.76 & 1.66 & 1.77 & 1.97 & 1.79 & 1.73 & 1.83 \\
\hline & & 1.86 & 1.80 & 1.72 & 1.79 & 2.08 & 1.92 & 1.81 & 1.94 \\
\hline & & 1.63 & 1.60 & 1.49 & 1.57 & 1.81 & 1.72 & 1.45 & 1.66 \\
\hline \multicolumn{2}{|r|}{ Mean } & 1.80 & 1.72 & 1.60 & 1.70 & 1.93 & 1.80 & 1.65 & 1.79 \\
\hline \multirow{4}{*}{2500} & Urea & 1.89 & 1.88 & 1.87 & 1.88 & 1.94 & 1.92 & 1.79 & 1.88 \\
\hline & \multirow{3}{*}{$\begin{array}{c}\text { Amm. Sulphate } \\
\text { Ammonium } \\
\text { nitrate } \\
\text { Anhydrous } \\
\text { Ammonia }\end{array}$} & 1.93 & 1.83 & 1.75 & 1.84 & 2.03 & 1.85 & 1.76 & 1.88 \\
\hline & & 1.94 & 1.86 & 1.94 & 1.91 & 2.18 & 2.07 & 1.96 & 2.07 \\
\hline & & 1.76 & 1.70 & 1.57 & 1.68 & 1.89 & 1.84 & 1.65 & 1.79 \\
\hline \multicolumn{2}{|r|}{ Mean } & 1.88 & 1.82 & 1.78 & 1.83 & 2.01 & 1.92 & 1.79 & 1.91 \\
\hline \multirow{4}{*}{2000} & Urea & 1.98 & 1.96 & 1.90 & 1.95 & 2.02 & 1.99 & 1.84 & 1.95 \\
\hline & \multirow{3}{*}{$\begin{array}{c}\text { Amm. Sulphate } \\
\text { Ammonium } \\
\text { nitrate } \\
\text { Anhydrous } \\
\text { Ammonia }\end{array}$} & 1.98 & 1.88 & 1.78 & 1.88 & 2.11 & 1.90 & 1.81 & 1.94 \\
\hline & & 2.06 & 1.95 & 1.89 & 1.97 & 2.23 & 2.15 & 1.99 & 2.12 \\
\hline & & 1.83 & 1.79 & 1.63 & 1.75 & 1.97 & 1.91 & 1.74 & 1.87 \\
\hline \multicolumn{2}{|c|}{ Mean } & 1.96 & 1.90 & 1.80 & 1.89 & 2.08 & 1.99 & 1.85 & 1.97 \\
\hline \multicolumn{2}{|c|}{ Grand mean } & 1.88 & 1.81 & 1.73 & & 2.01 & 1.90 & 1.76 & \\
\hline \multirow{4}{*}{ 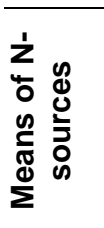 } & \multirow{4}{*}{\begin{tabular}{|c|} 
Urea \\
Amm. Sulphate \\
Ammonium \\
nitrate \\
Anhydrous \\
Ammonia \\
\end{tabular}} & 189 & 185 & 177 & 181 & 193 & 189 & 175 & \\
\hline & & 1.93 & 1.82 & 1.73 & 1.83 & 2.04 & $\begin{array}{l}1.09 \\
1.85\end{array}$ & $\begin{array}{l}1.75 \\
1.77\end{array}$ & $\begin{array}{l}1.00 \\
1.88\end{array}$ \\
\hline & & 1.95 & 1.87 & 1.85 & 1.89 & 2.16 & 2.05 & 1.92 & 2.04 \\
\hline & & & & & 1.67 & & & 1.61 & 1.77 \\
\hline \multicolumn{10}{|c|}{ LSD at 0.05: } \\
\hline \multirow{2}{*}{\multicolumn{5}{|c|}{$\begin{array}{l}\text { Irrigation } \\
\text { N-Sources }\end{array}$}} & \multirow{2}{*}{\multicolumn{4}{|c|}{$\begin{array}{l}0.05 \\
0.07\end{array}$}} & 0.05 \\
\hline & & & & & \multicolumn{3}{|l|}{0.07} & & 0.06 \\
\hline \multicolumn{2}{|c|}{ N- Rates } & & & & & 0.05 \\
\hline \multirow{2}{*}{\multicolumn{2}{|c|}{$\begin{array}{l}\text { Irrigation x N-Sources } \\
\text { Irrigation x N-Rates }\end{array}$}} & & & & \multirow{2}{*}{\multicolumn{4}{|c|}{$\begin{array}{l}0.09 \\
0.03\end{array}$}} & 0.06 \\
\hline \multirow{2}{*}{\multicolumn{2}{|c|}{$\begin{array}{l}\text { Irrigation x N-Rates } \\
\text { N-Sources x N-Rates }\end{array}$}} & & & & & & & & 0.05 \\
\hline & & & & & \multirow{2}{*}{\multicolumn{4}{|c|}{$\begin{array}{l}0.07 \\
0.05\end{array}$}} & 0.07 \\
\hline \multicolumn{5}{|c|}{ Irrigation x N-Sources x N-Rates } & & & & & 0.05 \\
\hline
\end{tabular}


Soliman, E. M. et al.

Table 8: Average purity\% in root juice of sugar beet as affected by irrigation regime, nitrogen sources, nitrogen rates and their interactions in 2010/2011 and 2011/2012 seasons.

\begin{tabular}{|c|c|c|c|c|c|c|c|c|c|c|}
\hline \multirow{2}{*}{\multicolumn{3}{|c|}{ Treatments }} & \multirow{2}{*}{\multicolumn{4}{|c|}{$\begin{array}{l}\text { 2010/2011 season } \\
\text { N-Rates }\left({\left.\mathrm{kg} \mathrm{N} / \text { fed }^{-1}\right)}^{-1} \text { ) }\right.\end{array}$}} & \multirow{2}{*}{\multicolumn{4}{|c|}{$\begin{array}{c}\text { 2011/2012 season } \\
\text { N-Rates }\left(\mathrm{kg} \mathrm{N} / \mathrm{fed}^{-1}\right)\end{array}$}} \\
\hline & & & & & & & & & & \\
\hline \multicolumn{2}{|c|}{$\begin{array}{c}\text { Irrigation } \\
\text { regime } \\
\left(\mathrm{m}^{3} \mathbf{f}^{-1}\right)\end{array}$} & $\begin{array}{c}\mathrm{N}- \\
\text { Sources }\end{array}$ & 70 & 80 & 90 & Mean & 70 & 80 & 90 & Mean \\
\hline \multirow{3}{*}{3000} & \multicolumn{2}{|c|}{$\begin{array}{c}\text { Urea } \\
\text { Amm. Sulphate }\end{array}$} & $\begin{array}{l}83.90 \\
80.00\end{array}$ & $\begin{array}{l}81.70 \\
78.20\end{array}$ & $\begin{array}{l}80.30 \\
78.00\end{array}$ & $\begin{array}{l}81.97 \\
78.73\end{array}$ & $\begin{array}{l}85.30 \\
81.40\end{array}$ & $\begin{array}{l}82.80 \\
79.50\end{array}$ & $\begin{array}{l}81.20 \\
79.10\end{array}$ & $\begin{array}{l}83.10 \\
80.00\end{array}$ \\
\hline & \multicolumn{2}{|c|}{$\begin{array}{l}\text { Ammonium } \\
\text { nitrate }\end{array}$} & 79.30 & 78.90 & 78.20 & 78.80 & 80.90 & 80.00 & 79.10 & 80.00 \\
\hline & \multicolumn{2}{|c|}{$\begin{array}{l}\text { Anhydrous } \\
\text { Ammonia }\end{array}$} & 82.50 & 81.90 & 81.30 & 81.90 & 83.90 & 82.60 & 80.10 & 82.20 \\
\hline \multicolumn{3}{|c|}{ Mean } & 81.43 & 80.18 & 79.45 & 80.35 & $\mid 82.88$ & \begin{tabular}{|l|l|}
81.23 \\
\end{tabular} & \begin{tabular}{|l}
79.88 \\
\end{tabular} & 81.33 \\
\hline \multirow{4}{*}{2500} & \multirow{2}{*}{\multicolumn{2}{|c|}{ Amm. Sulphate }} & 84.90 & 83.10 & 82.70 & 83.57 & 86.10 & 84.20 & 83.80 & 4.70 \\
\hline & & & 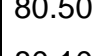 & 30 & 0 & 10 & 82.10 & 80.90 & 00 & 81.00 \\
\hline & \multicolumn{2}{|c|}{$\begin{array}{l}\text { Ammonium } \\
\text { nitrate }\end{array}$} & 80.10 & 79.50 & 79.00 & 79.53 & 81.50 & 80.90 & 80.60 & 81.00 \\
\hline & \multicolumn{2}{|c|}{$\begin{array}{l}\text { Anhydrous } \\
\text { Ammonia }\end{array}$} & 84.20 & 83.90 & 81.20 & 83.10 & 86.00 & 85.10 & 84.30 & 85.13 \\
\hline \multicolumn{3}{|c|}{ Mean } & 82.43 & 81.45 & 80.33 & 81.40 & 83.93 & \begin{tabular}{|l|l|}
82.78 \\
\end{tabular} & 82.18 & 82.96 \\
\hline \multirow{4}{*}{2000} & \multirow{2}{*}{\multicolumn{2}{|c|}{$\begin{array}{c}\text { Urea } \\
\text { Amm. Sulphate }\end{array}$}} & 86.00 & \begin{tabular}{|l|l}
85.10 \\
\end{tabular} & 84.10 & 85.10 & 87.30 & \begin{tabular}{|l|l}
86.30 \\
\end{tabular} & 85.60 & 86.40 \\
\hline & & & 81.80 & 80.70 & 79.60 & 80.70 & 83.10 & 81.80 & 80.90 & 81.93 \\
\hline & \multicolumn{2}{|c|}{$\begin{array}{l}\text { Ammonium } \\
\text { nitrate }\end{array}$} & 81.80 & 80.60 & 80.20 & 80.87 & 82.30 & 81.70 & 81.10 & 81.70 \\
\hline & \multicolumn{2}{|c|}{$\begin{array}{l}\text { Anhydrous } \\
\text { Ammonia }\end{array}$} & 86.20 & 85.60 & 85.00 & 85.60 & 88.10 & 87.20 & 86.00 & 87.10 \\
\hline & $\mathrm{Me}$ & & 95 & 0 & 3 & 83.06 & 5.20 & 25 & 8 & 84.28 \\
\hline \multicolumn{3}{|c|}{ Grand mean } & 82.60 & 81.54 & 00.0 & & 4.00 & \begin{tabular}{|l|l}
82.75 \\
\end{tabular} & & \\
\hline \multirow{4}{*}{ 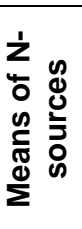 } & \multirow{4}{*}{\multicolumn{2}{|c|}{\begin{tabular}{|c|} 
Urea \\
Amm. Sulphate \\
Ammonium \\
nitrate \\
Anhydrous \\
Ammonia \\
\end{tabular}}} & 84.93 & 83.30 & | 82.37 & 83.50 & 86.23 & 84.43 & 83.53 & 84.73 \\
\hline & & & 80.77 & 79.40 & - & 79.61 & 82.20 & 80.73 & & 80. \\
\hline & & & 80.40 & 79.67 & 79.13 & 79.73 & 81.57 & 80.87 & 80.27 & 80.90 \\
\hline & & & 84.30 & 83.80 & 82.50 & 83.53 & 86.00 & 84.97 & 83.47 & 84.81 \\
\hline \multirow{7}{*}{\multicolumn{3}{|c|}{$\begin{array}{l}\text { LSD at 0.05: } \\
\text { Irrigation } \\
\text { N-Sources } \\
\text { N-Rates } \\
\text { Irrigation x N-Sources } \\
\text { Irrigation x N-Rates } \\
\text { N-Sources x N-Rates } \\
\text { Irrigation x N-Sources }\end{array}$}} & & & & & & & & \\
\hline & & & & & & & & & & \\
\hline & & & & & & & & & & \\
\hline & & & & & & & & & & \\
\hline & & & & & & & & & & \\
\hline & & & & & & & & & & \\
\hline & & & & & & 0. & & & & 0.70 \\
\hline
\end{tabular}




\section{REFERENCES}

Abd- El- Kader, E.M.A. (2011). Effect of nitrogen fertilizer rates and some growth regulators treatments on sugar beet. J. plant Prod. Mansoura Univ.; 2 (2): 1693-1702.

Chapman, H. D. and P.F. Pratt (1961). Methods of analysis for soils, plant and waters. Division of Agric. Sci., Univ. of California.

EL-Sarag, E.I. (2009). Maximizing sugar beet yield quality and water use efficiency using some agricultural practices under North Sinai conditions. Bull Fac. Agric. Cairo Univ., 60: 2.

El-Sonbaty, M.M.; G.H. Abdel-Hay; E.A.E. Nemeat-Alla and E.A. El-Tahawey (2012). Effect of source, rate and application time of nitrogen fertilizer on sugar beet. J. plant Prod. Mansoura Univ., 3 (11): 2903-2912.

Fathy , M.F.A. and K.K. Attia (2009). Response of sugar beet plants to nitrogen and potassium fertilization in sandy calcareous soil. International soil J. of Agric. Biology, 11(6) :695-700.

Gomez, K.A. and A.A. Gomez (1984). Statistical procedures for agricultural research An International Rice Research institute Book John Willey and Sons. Ince., New York.

Leilah. A.A., M.A. Badawi; E.M. Said; M.H. Ghonema and M. A.E.A. Bdou (2005). Effective planting dates, plant population and nitrogen fertilization on sugar beet productivity under the newly reclaimed sandy soils in Egypt. Scientific of King Faisal Univ. (basic and applied sciences). 6 (1): 95-110.

Nemeat-Alla, H.E.A.E. (2009). Effect of nitrogen and boron fertilization on productility and quality of sugar beet under different planting patterns. Ph. D. Thesis Fac. Agric. Kafer El-Sheikh Univ. Egypt .

Parashar, U.K.; R.K. Choudhary and C.K. Singh (1976). Studies on the response of sugar beet to irrigation and its economics in relation to root and sugar yield. Indian J. Agron. 21(2): 88-91.

Ramazan, T.; S.H. Sinan and A. Bilal (2011). Effect of different drip irrigation regimes on sugar beet (Beta vulgaris L.) yield, quality and water use efficiency in Middle Anatolian, Turkey. Irrig. Sci. , 29: 79-89.

Tsialtas, J.T. and N. Masalris (2005). Effect of $\mathrm{N}$ fertilization rate on sugar yield and non sugar impurities of sugar beet (Beta Vulgaris L.) grown under mechterra Mediterranean condition . J. Agron. and Crop Sci., 191 (5): 330-339. 


\section{تأثير كميـات ميـاة الرى ومصسادر ومعدلات النيتروجين على نمو وجودة محصول بنجز السكر

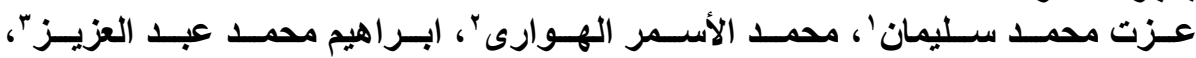

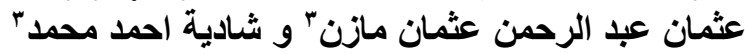

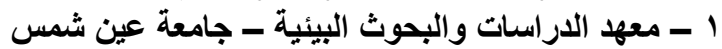

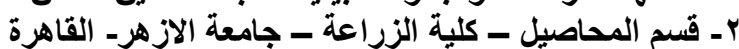

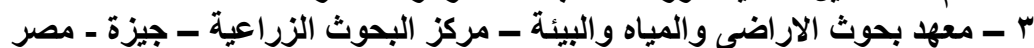

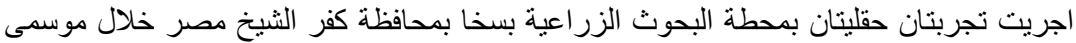

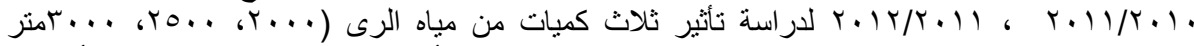

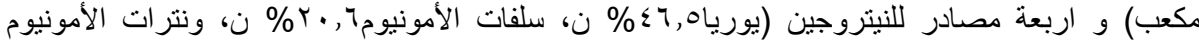

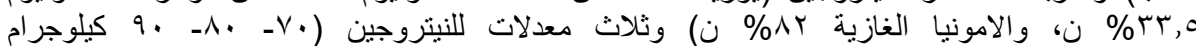
نيتروجين/للفدان) على نمو وجودة بنجر السكر. صمدت التجربة فى تصميم قطع منشقة مرة واحدة فى اربع

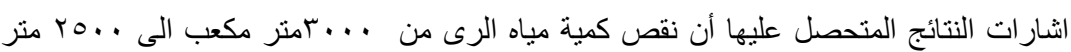

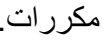

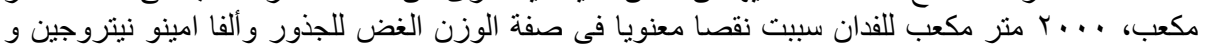

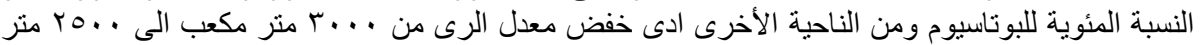

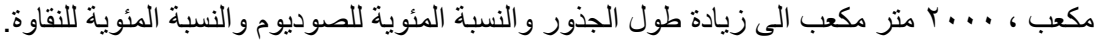

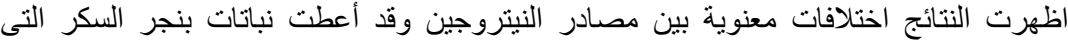

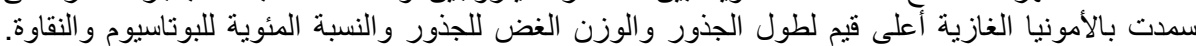
و على العكس من ذلك أعطت هذه النباتات أقل القيم للنسبة المئوية للفا امينو نيتروجين والنئ والنسبة المئوية

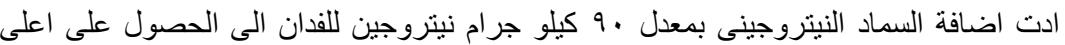
للصوديوم.

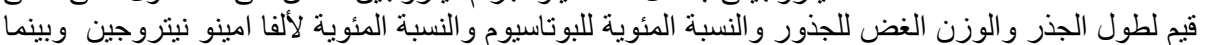

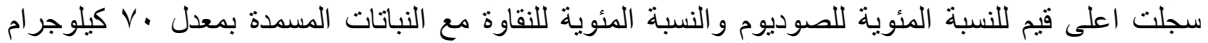
نيتروجين للفدان بالمقارنة مع المعدلات الأخرى.

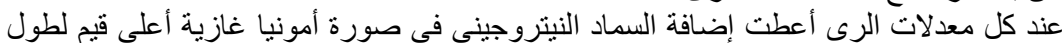

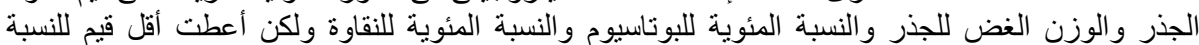

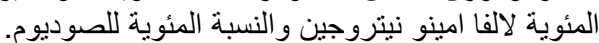

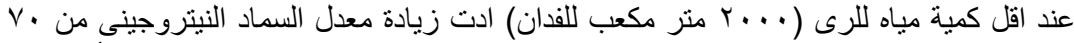

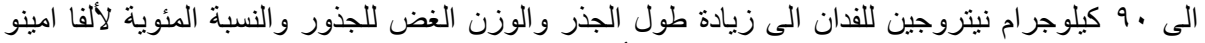

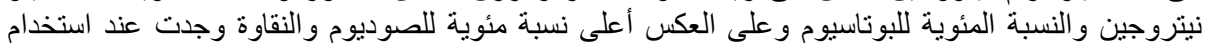

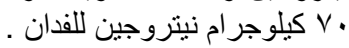

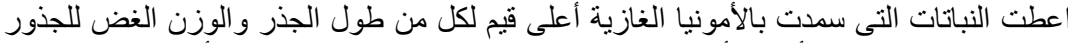

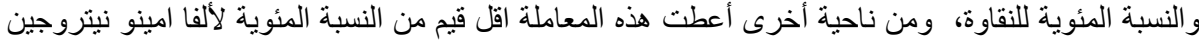

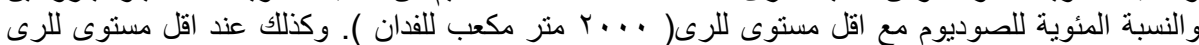
(r F r...) جذر وأثقل جذور واعلى نسبة مئوية للبوتاسيوم والنقاوة، وعلى العكس من ذلك ألك أعطت أقل نسبة مئوية لألفا

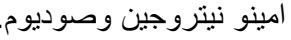

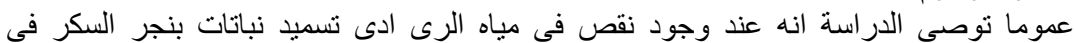

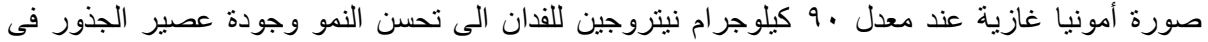
نباتات بنجر السكر صنف Gloriuf تحت ظروف سخا محافظة كفر الثيخ. 
J. Plant Production, Mansoura Univ., Vol. 4 (4), April, 2013

كلية الزراعة - جامعة المنصورة

كلية الزراعة - جامعة الأزهر
قام بتحكيم البحث

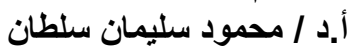

أ. أد / منير عبد الله عبد العزيز 